\title{
Silvicultural Attempts to Induce Browse Resistance in Conifer Seedlings
}

\author{
Bruce A. Kimball, ${ }^{1,2}$ Fred Pfund, ${ }^{3}$ Mark Gourley, ${ }^{3}$ Doreen L. Griffin, ${ }^{1,4}$ and John H. Russell ${ }^{5}$ \\ ${ }^{1}$ United States Department of Agriculture, Animal and Plant Health Inspection Service, Wildife Services, \\ National Wildife Research Center, Fort Collins, CO, USA \\ ${ }^{2}$ Monell Chemical Senses Center, 3500 Market Street, Philadelphia, PA 19104, USA \\ ${ }^{3}$ Starker Forests, Inc., 7240 SW Philomath Boulevard, Corvallis, OR 97339, USA \\ ${ }^{4}$ United States Department of Agriculture, Animal and Plant Health Inspection Service, Wildife Services, \\ National Wildlife Research Center, 4101 LaPorte Avenue, Fort Collins, CO 80521, USA \\ ${ }^{5}$ British Columbia Ministry of Forests and Range, Research, Innovation and Knowledge Management Branch, \\ Cowichan Lake Research Station, P.O. Box 335, 7060 Forestry Road, Mesachie Lake, BC, Canada VOR 2NO
}

Correspondence should be addressed to Bruce A. Kimball, bruce.a.kimball@aphis.usda.gov

Received 31 December 2010; Revised 28 February 2011; Accepted 15 April 2011

Academic Editor: Michael Tausz

Copyright (C) 2011 Bruce A. Kimball et al. This is an open access article distributed under the Creative Commons Attribution License, which permits unrestricted use, distribution, and reproduction in any medium, provided the original work is properly cited.

\begin{abstract}
A multiyear study was conducted to determine if soil amendment combined with topical application of elemental sulfur could be employed to reduce deer browse damage to four conifer species. Fertilizer and sulfur were applied to conifer seedlings at seven sites near Corvallis, OR. Growth and browse damage data were collected for all seedlings over a period of 17 months. Additionally, foliar concentrations of monoterpenes and simple carbohydrates were assessed in western redcedar (Thuja plicata) seedlings over a period of three years. Fertilization and sulfur treatments had a moderate impact on growth and no influence on browse damage or the chemical responses. Over the course of the study, browse damage diminished while foliar monoterpene concentrations increased in redcedar. It appears that silvicultural manipulation via sulfur application and/or soil amendment cannot accelerate or alter the ontogenetical changes that may naturally defend seedlings against mammalian herbivores. In a brief trial with captive deer, redcedar browse resistance was influenced by seedling maturation, but not monoterpene content. Other maturation effects may yield significant browse protection to young seedlings.
\end{abstract}

\section{Introduction}

Ever-increasing populations of deer are having dramatic effects on ecosystem processes in temperate and boreal forests [1]. Among these varied and widespread effects are significant growth losses in plantation forests [2]. Although few studies have quantified the economic impacts of deer browse to forest crops, a recent evaluation of net present value (NPV) of Sitka spruce (Picea sitchensis (Bong.) Carr.) demonstrated significant NPV declines when $55 \%$ or more of the trees became multistemmed at harvest as a result of seedling browse to the apical meristem [3]. Even in the absence of deformed trees, delayed establishment (growth cost of regenerating lost tissues) resulted in precipitous declines of NPV.

Plant-herbivore interactions are subject to dynamic influences at multiple scales. Factors such as plant heterogeneity, herbivore density, and predation risk impact foraging behavior at large scales such as plot selection, residence time, and bout duration [4-6]. At smaller scales, plant characteristics such as individual defense and neighbor effects impact diet selection of specific plants or plant parts [7-9]. Fine-scale diet preferences are constrained by herbivore anatomy and physiology and influenced by the individuals' experience with the food [10]. Management tools employed to reduce deer damage in managed forests 
similarly act at multiple scales. For example, population management, dispersal, and exclusion have been used to impact large herbivore behavior at large scales [11]. Exclusion can also be employed at finer scale in the form of individual tree barriers or bud caps [12]. Additionally, a wide variety of topically applied repellents have been used to impact diet selection behavior with varied success $[13,14]$.

Silvicultural approaches to alleviating browse damage can be employed at multiple scales. Site preparation and clear-cutting techniques have been tested for their impacts on ungulate dispersal and land use $[11,15]$. Silvicultural manipulations may also alter individual plant phytochemistry to impact fine-scale browsing behavior $[16,17]$. Several theories have been introduced to describe the occurrence and distribution of chemical defenses in plants. These theories put forward the knowledge that phytochemicals are regulated by genetics and influenced by environment [18-20]. For example, among eucalyptus genotypes with different constitutive levels of defense, fertilization treatment increased monoterpene (1,8-cineole) and structural (lignin) defenses in all genotypes [21]. Soil nutrient content has been shown to influence production of monoterpenes in many plant species to varying extent [22-25].

It follows that deer browse damage may be reduced in managed plantations by manipulating the distribution phytochemicals in seedlings such that plant palatability is reduced. Examination of black-tailed deer (Odocoileus hemionus) preference for western redcedar (Thuja plicata) foliage indicated that forage preferences were based, in part, on the plant chemical constituents $[26,27]$. Specifically, deer preferred plants and test foods with low monoterpene concentrations. In western redcedar, the predominant monoterpene is the bicyclic ketone, $\alpha$-thujone [28].

The objective of the present study was to examine finescale plant-herbivore interactions by determining if seedling palatability could be altered via silvicultural manipulation. We experimentally tested the effect of soil nutrient amendment (for increased growth and disease resistance) and topical application of elemental sulfur (used to combat the Swiss Needle Cast fungus) to lower browsing damage caused by deer on conifer seedlings. Anecdotal observations indicated that these treatments may reduce deer browsing. In addition to measuring browse and growth responses in multiple conifer species, foliar concentrations of monoterpenes and monosaccharides were determined in western redcedar in response to the silvicultural treatments.

\section{Methods}

2.1. Multispecies Browse and Growth Study. Four conifer species were planted in three blocks at each of seven sites located in the coastal range near Corvallis, OR, USA (Table 1). Prior to planting, soil analyses were conducted by a contract laboratory to determine preexperimental soil chemistry profiles (Table 2). Each block was comprised of four treatment plots each consisting of 10 rows (Figure 1). Each row contained 10 trees of the same species. There were four rows of western redcedar, and two rows each of western

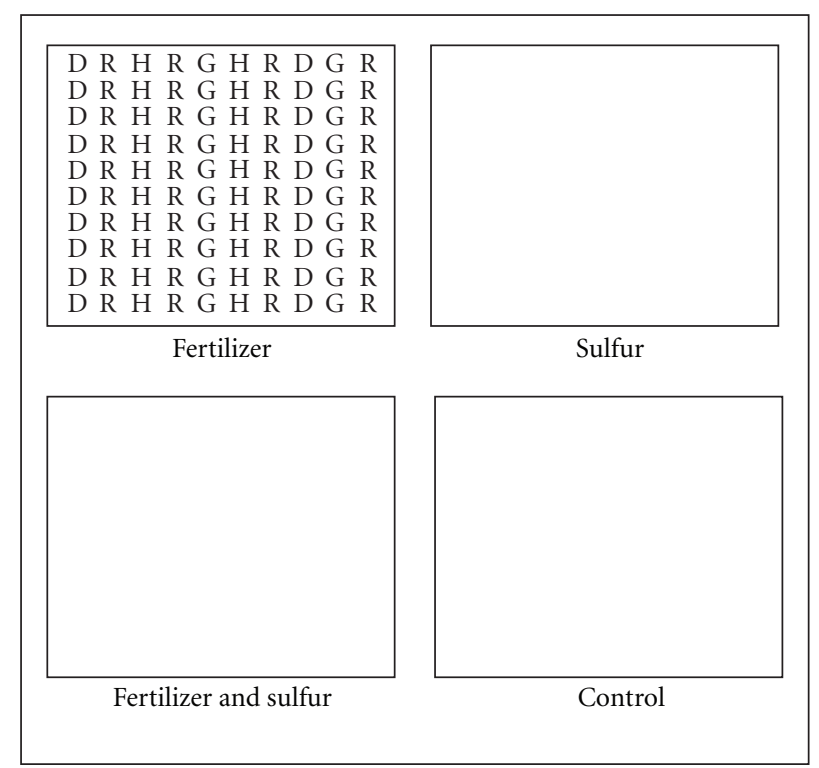

FIGURE 1: Block layout: three replicate blocks located at seven sites in Western Oregon were employed for the field experiment. Four treatment plots (whole plot) contained four species (split-plot) of conifers planted in rows of ten seedlings (D: Douglas-fir; G: grand fir; H: western hemlock; R: western redcedar).

TABLE 1: Field site locations in Western Oregon.

\begin{tabular}{lcc}
\hline Name & Longitude & Latitude \\
\hline Alder Creek & $123^{\circ} 21.5163^{\prime} \mathrm{W}$ & $44^{\circ} 38.1974^{\prime} \mathrm{N}$ \\
Black Bear & $123^{\circ} 29.5507^{\prime} \mathrm{W}$ & $44^{\circ} 27.1579^{\prime} \mathrm{N}$ \\
Hatchery View & $123^{\circ} 33.9968^{\prime} \mathrm{W}$ & $44^{\circ} 25.1491^{\prime} \mathrm{N}$ \\
Huffman & $123^{\circ} 45.6084^{\prime} \mathrm{W}$ & $44^{\circ} 37.8736^{\prime} \mathrm{N}$ \\
Rhubarb & $123^{\circ} 30.7554^{\prime} \mathrm{W}$ & $44^{\circ} 38.8319^{\prime} \mathrm{N}$ \\
Shot Pouch & $123^{\circ} 36.0456^{\prime} \mathrm{W}$ & $44^{\circ} 34.3925^{\prime} \mathrm{N}$ \\
Stuck Creek & $123^{\circ} 29.2894^{\prime} \mathrm{W}$ & $44^{\circ} 34.2192^{\prime} \mathrm{N}$ \\
\hline
\end{tabular}

hemlock (Tsuga heterophylla), Douglas-fir (Pseudotsuga menziesii), and grand fir (Abies grandis). All sites were planted in the spring of 2003.

Fertilization and topical sulfur were applied to treatment plots in three combinations (fertilizer only, sulfur only, and both fertilizer and sulfur) along with a control (no treatment). Nutrients ( $\mathrm{Ca}, \mathrm{Mg}, \mathrm{K}, \mathrm{Fe}, \mathrm{Cu}, \mathrm{Zn}, \mathrm{B}$, and $\mathrm{S}$ ) were added to the soil in three yearly increments early each spring (Table 3). The application rate of each nutrient was based on pre-experiment soil analyses for each site resulting in equivalent nutrient concentrations in treatment plots across all sites (accounting for native soil concentrations). Plots were fertilized in the spring of 2003, 2004, and 2005. Elemental sulfur was topically applied to foliage with an adhesive early each summer in 2003, 2004, and 2005.

Growth and browse data were collected from each individual tree in May 2003, September 2003, and October 2004. During data collection, the height and caliper of each tree was measured and the percentage of tree remaining was estimated by visual estimation of lateral branch loss in 
TABLe 2: Preexperimental soil chemistry determined at the seven study sites.

\begin{tabular}{lcccccccc}
\hline Nutrient & Unit & Alder creek & Black bear & Hatchery view & Huffman & Rhubarb & Shot pouch & Stuck creek \\
\hline Phosphates $\left(\right.$ as $\left.\mathrm{P}_{2} \mathrm{O}_{5}\right)$ & $\mathrm{Kg} / \mathrm{Ha}$ & 5509.3 & 731.4 & 3078.9 & 1640.8 & 2441.6 & 2590.6 & 3171.8 \\
Calcium & $\mathrm{Kg} / \mathrm{Ha}$ & 2844.8 & 193.8 & 1447.0 & 702.2 & 689.9 & 835.5 & 949.8 \\
Magnesium & $\mathrm{Kg} / \mathrm{Ha}$ & 743.7 & 210.6 & 818.7 & 847.8 & 630.6 & 866.9 & 874.7 \\
Potassium & $\mathrm{Kg} / \mathrm{Ha}$ & 112.0 & 82.9 & 81.8 & 89.6 & 81.8 & 79.5 & 76.2 \\
Sodium & $\mathrm{Kg} / \mathrm{Ha}$ & 0.9 & 0.6 & 0.7 & 0.5 & 0.5 & 1.0 & 0.6 \\
Boron & $\mathrm{ppm} *$ & 0.8 & 0.6 & 0.6 & 0.5 & 0.4 & 0.9 & 0.5 \\
Iron & $\mathrm{ppm}$ & 71.0 & 94.0 & 33.0 & 51.0 & 142.0 & 93.0 & 50.0 \\
Manganese & $\mathrm{ppm}$ & 156.0 & 83.0 & 154.0 & 114.0 & 146.0 & 196.0 & 294.0 \\
Copper & $\mathrm{ppm}$ & 5.8 & 1.6 & 1.6 & 0.8 & 1.2 & 1.0 & 5.1 \\
Zinc & $\mathrm{ppm}$ & 4.2 & 3.1 & 4.0 & 3.6 & 3.8 & 3.5 & 4.9 \\
Sulfur & $\mathrm{ppm}$ & 18.0 & 13.0 & 10.0 & 13.0 & 13.0 & 12.0 & 10.0 \\
\hline
\end{tabular}

${ }^{*}$ ppm: parts per million or $\mathrm{mg} / \mathrm{Kg}$.

TABle 3: Summary of spring-season soil fertilization application rates $(\mathrm{Kg} / \mathrm{Ha})$ at the seven study sites (X: application; O: no application). Foliage was sampled for phytochemical analyses in fall of 2003, 2004, and 2005.

\begin{tabular}{lccccc}
\hline Mineral & Min & Max & 2003 & 2004 & 2005 \\
\hline Sulfur & 30.6 & 36.7 & $\mathrm{X}^{\mathrm{a}}$ & $\mathrm{X}^{\mathrm{a}}$ & $\mathrm{X}^{\mathrm{a}}$ \\
Lime & 220.1 & 2996.4 & $\mathrm{X}$ & $\mathrm{X}$ & $\mathrm{X}$ \\
Dolomite & 1125.2 & 3130.9 & $\mathrm{X}^{\mathrm{b}}$ & $\mathrm{X}^{\mathrm{b}}$ & $\mathrm{X}^{\mathrm{b}}$ \\
Potassium sulfate & 220.1 & 562.6 & $\mathrm{X}$ & $\mathrm{O}^{\mathrm{c}}$ & $\mathrm{O}^{\mathrm{d}}$ \\
Iron (II) sulfate & 48.9 & 458.6 & $\mathrm{X}$ & $\mathrm{O}$ & $\mathrm{O}$ \\
Copper sulfate & 6.1 & 28.1 & $\mathrm{X}^{\mathrm{e}}$ & $\mathrm{O}^{\mathrm{f}}$ & $\mathrm{O}$ \\
Zinc sulfate & 24.5 & 36.7 & $\mathrm{X}$ & $\mathrm{O}$ & $\mathrm{O}$ \\
Boron & 12.2 & 17.1 & $\mathrm{O}$ & $\mathrm{X}$ & $\mathrm{O}$ \\
Nitrogen-Phosphorous- & 281.3 & 281.3 & $\mathrm{O}$ & $\mathrm{O}$ & $\mathrm{X}$ \\
Potassium (11-52-0) & & & & & \\
\hline
\end{tabular}

${ }^{a}$ Sulfur was applied topically to foliage in summer season.

${ }^{\mathrm{b}}$ No dolomite was applied in any year at the Alder Creek site.

'Potassium sulfate was applied at Black Bear and Huffman sites in 2004.

dPotassium sulfate was applied at Black Bear in 2005.

${ }^{e}$ No copper sulfate was applied at Alder Creek and Stuck Creek sites in 2003.

${ }^{\mathrm{f}}$ Copper sulfate was applied (minimum rate) at Alder Creek and Stuck Creek sites in 2003.

$5 \%$ increments. A value of 100 was assigned to individuals that had not sustained browse damage. Dead trees were replaced at the time of measurement; however, responses for replacement trees were not included in the analyses.

Mean height, caliper, and browse (percent leaf area) responses were calculated for each treatment plot by species and collection date. Responses were subjected to statistical analyses as a split-plot design with repeated measures using the MIXED procedure in SAS [29]. Restricted maximum likelihood (REML) estimation was specified as was the Satterthwaite method for determining degrees of freedom. Unstructured covariance structures were employed for repeated measures of species and treatment. For the browse response, site and block were random effects, while treatment (fertilizer only, sulfur only, both fertilizer and sulfur, and control), tree species (western hemlock, Douglasfir, grand fir, and western redcedar), and data collection date were fixed effects. Growth (height and caliper) responses were similarly analyzed except that the browse response was considered a covariate to account for the effect of browsing on tree growth. Comparisons of estimates were made using the false discovery rate procedure [30]. Model assumptions were tested by visually inspecting plots of studentized residuals versus predicted responses (constant variance assumption) and normal probability plots (normal distribution assumption).

2.2. Western Redcedar Phytochemical Analyses. Three composite western redcedar foliage samples were collected from each treatment plot in fall of 2003, 2004, and 2005. Composites consisted of two cuttings taken from each of four redcedar seedlings (Figure 1). The four seedlings were identified in advance by their position in the row. No individual redcedar seedling was sampled more than once during the course of the study. For example, in 2003 seedlings assigned to positions 2, 6, and 9 in each redcedar row were sampled to yield three composite samples. Foliage samples were subjected to grinding, solvent extraction, and chromatographic analyses to determine the concentrations of several nonstructural carbohydrates (e.g., glucose, fructose) and monoterpenes (e.g., $\alpha$-pinene, sabinene, $\alpha$-thujone) according to previously described methods $[28,31]$.

Mean western redcedar phytochemical responses from analysis of the composite samples were calculated for each treatment plot by collection date and subjected to correlation analyses prior to analysis of variance. Glucose and $\alpha$ thujone treatment means from each plot were subjected to statistical analyses as a randomized complete block with repeated measures using the MIXED procedure in SAS [29]. Unstructured covariance structure was assumed for repeated measures of treatment. Site and block were random effects, while treatment (fertilizer only, sulfur only, both fertilizer and sulfur, and control) and collection date were fixed effects for the mixed model analysis of variance. Comparisons of estimates were made using the false discovery rate procedure [30]. Model assumptions were tested by visually inspecting plots of studentized residuals versus predicted responses (constant variance assumption) and normal probability plots (normal distribution assumption). 
2.3. Captive Deer Study. Two- and three-year-old redcedar seedlings (ca. $1 \mathrm{~m}$ tall) belonging to two monoterpene classes were planted in four contiguous blocks in a single 5 ha pen of the Olympia Field Station of the National Wildlife Research Center. "Low" monoterpene redcedar seedlings ranged in $\alpha$-thujone content from 25 to $35 \mathrm{mg} / \mathrm{g}$ and "high" monoterpene seedlings ranged from 45 to $65 \mathrm{mg} / \mathrm{g} \alpha$-thuone. Each block consisted of 32 seedlings ( 8 of each level of age and monoterpene class) randomly planted with $2 \times 2 \mathrm{~m}$ spacing. Twelve captive black-tailed deer were placed in the pen with water, pelleted basal diet, and shelter for two days. The trial, conducted February 2009, was approved by the Institutional Animal Care and Use Committee of the NWRC (protocol number QA-1662).

After two days, all seedlings were assessed for damage and given a score of 0 (no browse damage), 1 (less than 10 bites), 2 (more than 10 bites), or 3 (totally denuded). Visual evidence of as many as 15-20 bites is reasonably evident on larger seedlings. However, as it is impossible to ascertain if a solitary indication of browsing resulted from a single bite or a series of bites on the same lateral branch, classification into one of the four browse categories represents an effective method for rating browse severity. Browse scores were subjected to analysis of variance as a randomized complete block with seedling age $(2,3)$, monoterpene class (low, high), and the interaction fixed effects and block a random effect.

\section{Results}

3.1. Multispecies Browse Responses. Evaluation of diagnostic plots indicated that use of ANOVA was appropriate for all analyses. Soil and topical treatments did not impact browsing among any of the conifer species. Date $(P=0.045)$ and tree species $(P=0.003)$ were the only significant effects for the browse response (percent leaf area remaining). There was a significant browse preference for Douglas-fir and western redcedar versus grand fir and western hemlock (Figure 2). Browse was significantly lower in October 2004 relative to May 2003. The species $*$ date interaction was not decidedly significant $(P=0.07)$.

3.2. Multispecies Growth Responses. Tree height was subject to a strong species $*$ date interaction $(P<0.0001)$, while treatment approached significance $(P=0.059)$. The browse covariate was highly significant $(P<0.0001)$. Trees in plots receiving both fertilizer and sulfur were taller than trees in control or sulfur only plots. The minor increase in tree height produced by sulfur and fertilization $(0.8 \mathrm{~cm})$ is probably not sufficient to offer increased browse protection in the first few years of seedling growth. In May 2003, grand fir was the tallest species (Figure 3). However, between May 2003 and October 2004, western hemlock went from the shortest to the tallest species in the test plots. Caliper growth did not differ by treatment $(P=0.45)$, but species differences approached significance $(P=0.067)$. Not surprisingly, caliper increased significantly at each measurement date $(P=0.018)$. The browse covariate was also significant $(P=0.0006)$. No other effects were significant.

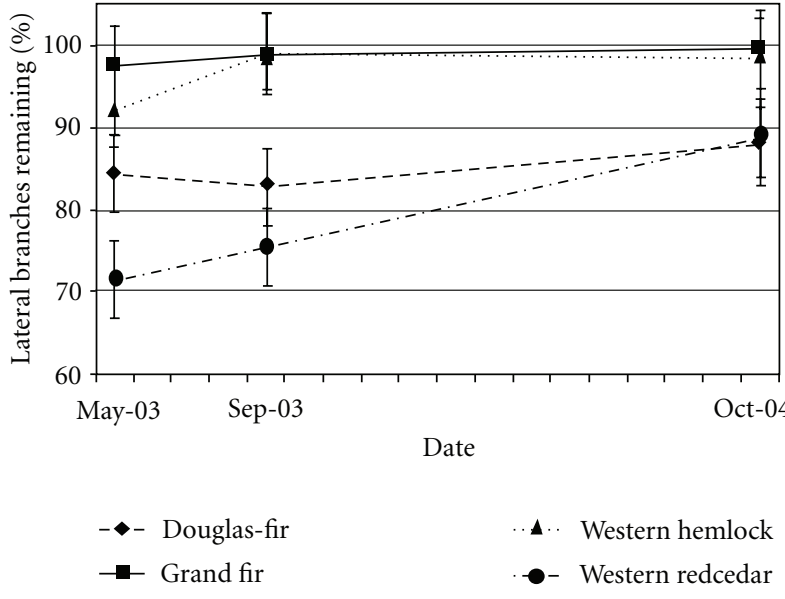

Figure 2: Percent of lateral branches remaining due to deer browsing for four conifer species planted in contiguous plots. Bars represent one standard error of the mean.

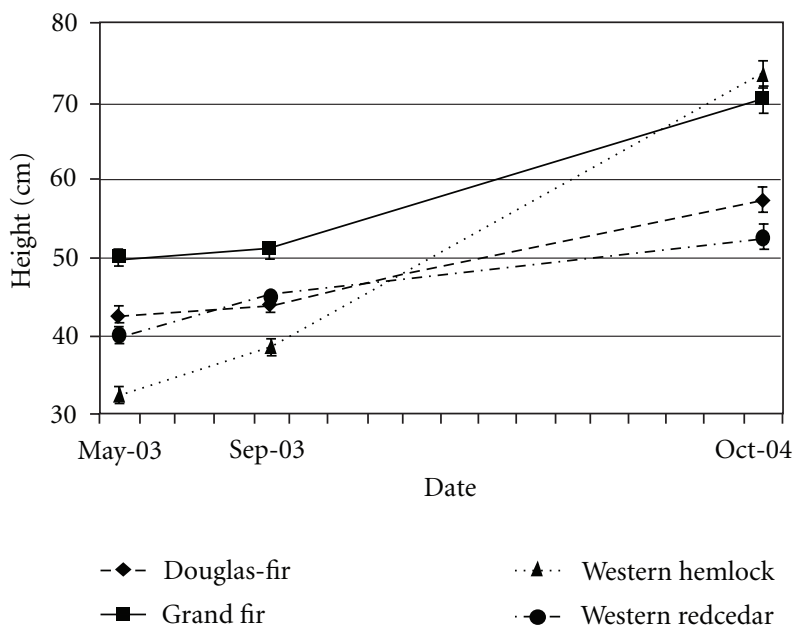

FIGURE 3: Height growth of four conifer species planted in contiguous plots. Bars represent one standard error of the mean.

3.3. Western Redcedar Foliar Phytochemistry. Glucose (mean concentration of $12 \mathrm{mg} / \mathrm{g}$ ) and fructose $(13 \mathrm{mg} / \mathrm{g}$ ) were the predominant carbohydrates identified in redcedar foliage. Sucrose was also present in many samples. Glucose and fructose concentrations were correlated $(r=0.42)$. The predominate monoterpenes identified in redcedar foliage were $\alpha$-thujone (mean concentration of $6.0 \mathrm{mg} / \mathrm{g}$ ), sabinene $(1.5 \mathrm{mg} / \mathrm{g}), \beta$-thujone $(0.6 \mathrm{mg} / \mathrm{g})$, myrcene $(0.5 \mathrm{mg} / \mathrm{g}), \alpha$ pinene $(0.3 \mathrm{mg} / \mathrm{g})$, and limonene $(0.1 \mathrm{mg} / \mathrm{g})$. Terpinolene, $\beta$ pinene, $\beta$-terpineol, and $\alpha$-thujene were also identified in most samples at much lower concentrations. Correlation analysis demonstrated that $\alpha$-thujone was highly correlated $(0.40<r<0.92)$ with all the quantified monoterpenes. Given these relationships, only glucose and $\alpha$-thujone responses were subjected to statistical analyses.

Treatment did not influence foliar $\alpha$-thujone concentration in redcedar $(P=0.88$; Figure 4$)$. However, monoterpene concentrations significantly increased over the three-year 


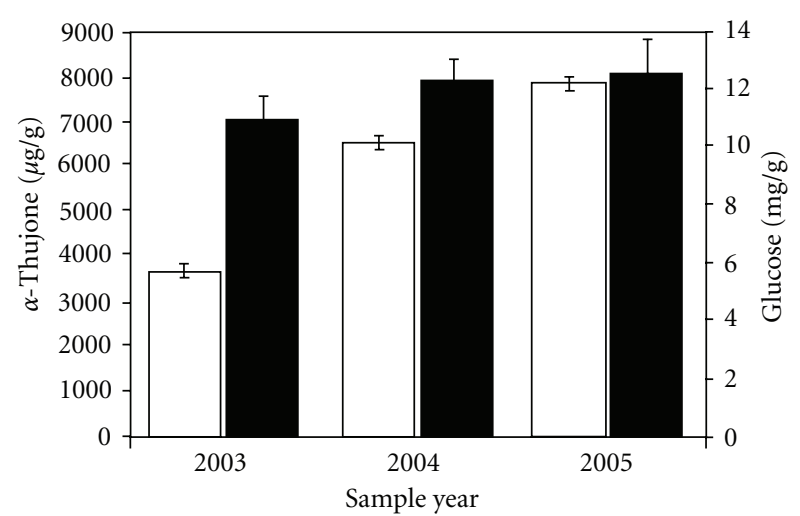

Glucose $\alpha$-Thujone

FIGURE 4: Foliar $\alpha$-thujone and glucose concentrations of western redcedar seedlings subjected to soil and topical treatments. Bars represent one standard error of mean.

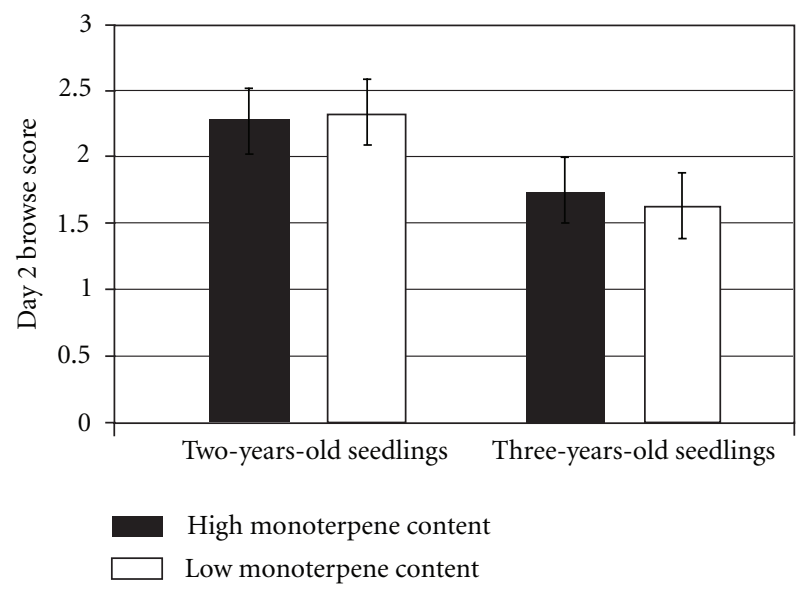

Figure 5: Mean browse scores (0: no browse damage; 1: less than 10 bites; 2: more than 10 bites; or 3: totally denuded) of redcedar seedlings offered to captive deer in a factorial design.

period of the study $(P<0.0001)$. Evaluation of glucose responses yields a similar conclusion: treatment did not impact foliar glucose concentration which was present at higher concentrations in 2004 and 2005 versus 2003.

3.4. Captive Deer Study. Browse damage to redcedar seedlings was impacted by seedling age $(P=0.0001)$, but not monoterpene content $(P=0.77)$ or the interaction $(P=0.36)$. Browse damage was significantly lower on threeyear-old trees (Figure 5).

\section{Discussion}

Western redcedar seedlings sustained the greatest browse damage among the four species tested in this study, particularly in the first year after-planting (Figure 2). Such anecdotal preference has been frequently reported. Relative to the other species, redcedar palatability is likely related to tactile and phytochemical properties. Expression of diet selection (finescale foraging behavior) is driven in large measure by the palatability of forage options. Palatability is the term that describes the interplay of flavor and postingestive feedbacks arising from the herbivore's experience with the food [32]. The herbivore's internal (experience through learning, nutritional state, etc.) and external (social facilitation, choice, etc.) environment interacts to define the palatability of specific foods. Plants contain both beneficial and deleterious phytochemicals that define palatability and determine which foods are eaten and how much. Preferences and aversions for specific food items arise from affective learning processes initiated by consumption [33]. Learning permits herbivores to regulate intake in accordance with the concentrations of nutrients and toxins in different foods that comprise the diet. As even the most toxic plants contain nutritious primary metabolites, herbivores can ill-afford to reject chemically defended plants outright. Likewise, even the most nutritious plants may contain some level of defenses. Thus, dietary preferences arise from a continuum of intake and feedbacks influenced by experience with the food [34], availability of alternatives [35], and plant toxicity [36].

Previous diet selection studies with deer have correlated palatability with monoterpene content of plants [26]. In highly controlled studies, captive deer were offered artificial test diets adulterated with monoterpenes [27, 37]. In all cases, deer preferred foods with lower concentrations of monoterpenes. It remains possible to exploit this phenomenon by employing reforestation strategies that promote increased production of plant secondary metabolites such as monoterpenes. This prospect is furthered by the knowledge that foliar phytochemistry is a highly heritable trait in conifers $[38,39]$, thus allowing for genetic selection for increased secondary metabolites based on familial information. However, none of the treatments employed in this study are likely to produce the desired effect. Furthermore, phytochemical analyses suggest that both monoterpene and monosaccharide production in western redcedar are likely governed by macroenvironmental and ontogenetic (plant development) factors not easily influenced by soil amendment and topical sulfur application.

While the treatments had no impact on browsing, ontogenetic changes in foliar phytochemistry may explain reduced browse damage in fall of 2004 versus 2003. For example, the $\alpha$-thujone concentration of redcedar seedlings nearly doubled during this period (Figure 4), while browse damage was significantly reduced (Figure 2). Interestingly, browsing of redcedar seedlings in the pen study was not impacted by monoterpene level (Figure 5). The lack of monoterpene effect was likely due to the relatively high foliar monoterpene concentration of the seedlings employed in the trial as compared to the range of monoterpenes present in the field trials (Figure 4). This suggests there may be some elevated monoterpene concentration at which deer no longer discriminate among individual plants. However, the significant age effect indicates that plant maturation may contribute other phenotypic attributes that influence browse preference. Changes in browse quality associated with plant tissue maturation can also be attributed to lignification [40]. 
Both monoterpene [41] and lignin [42] production in vascular plants are under genetic control. Thus, breeding selection for increased monoterpene and lignin content has great potential as a fine-scale approach to altering browse behavior. It may also be possible to employ alternative nursery practices for the production of so-called "browse resistant" seedlings. As evidenced by these data, each additional year of development in the nursery may significantly increase the foliar monoterpene concentration of conifer seedlings. However, successful protection of plantation forests from browse damage often requires integrated approaches that consider plant-herbivore interactions at multiple scales. Influencing diet selection alone is unlikely to afford complete protection when forage options are limited. Monoterpenes are not acutely toxic to mammalian herbivores [43] and large herbivores will ingest familiar toxic plants when alternatives are scarce or nutritious plants are unfamiliar [44]. Thus, successful regeneration in managed forests with high herbivore abundance may require protection of individual seedlings (e.g., constitutive defenses, repellents, or tree barriers) in combination with herbivore population management, dispersal, and/or exclusion [45].

\section{References}

[1] S. D. Côté, T. P. Rooney, J. P. Tremblay, C. Dussault, and D. M. Waller, "Ecological impacts of deer overabundance," Annual Review of Ecology, Evolution, and Systematics, vol. 35, pp. 113$147,2004$.

[2] R. M. A. Gill, "A review of damage by mammals in north temperate forests: 1. Deer," Forestry, vol. 65, no. 2, pp. 145$169,1992$.

[3] A. I. Ward, P. C. L. White, A. Smith, and C. H. Critchley, "Modelling the cost of roe deer browsing damage to forestry," Forest Ecology and Management, vol. 191, no. 1-3, pp. 301310, 2004.

[4] K. R. Searle, N. T. Hobbs, and L. A. Shipley, "Should I stay or should I go? Patch departure decisions by herbivores at multiple scales," Oikos, vol. 111, no. 3, pp. 417-424, 2005.

[5] D. J. van der Post and P. Hogeweg, "Resource distributions and diet development by trial-and-error learning," Behavioral Ecology and Sociobiology, vol. 61, no. 1, pp. 65-80, 2006.

[6] J. W. Christensen and M. Rundgren, "Predator odour per se does not frighten domestic horses," Applied Animal Behaviour Science, vol. 112, no. 1-2, pp. 136-145, 2008.

[7] W. J. Freeland and D. H. Janzen, "Strategies in herbivory by mammals-role of plant secondary compounds," The American Naturalist, vol. 108, no. 961, pp. 269-289, 1974.

[8] R. L. Senft, M. B. Coughenour, D. W. Bailey, L. R. Rittenhouse, O. E. Sala, and D. M. Swift, "Large herbivore foraging and ecological hierarchies," Bioscience, vol. 37, no. 11, pp. 789-799, 1987.

[9] S. Courant and D. Fortin, "Foraging decisions of bison for rapid energy gains can explain the relative risk to neighboring plants in complex swards," Ecology, vol. 91, no. 6, pp. 1841$1849,2010$.

[10] F. D. Provenza, "Tracking variable environments-there is more than one kind of memory," Journal of Chemical Ecology, vol. 21, no. 7, pp. 911-923, 1995.

[11] R. T. Graham, T. B. Jain, and J. L. Kingery, "Ameliorating conflicts among deer, elk, cattle and/or other ungulates and other forest uses: a synthesis," Forestry, vol. 83, no. 3, pp. 245$255,2010$.

[12] D. L. Nolte, "Behavioral approaches for limiting depredation by wild ungulates," in Grazing Behavior of Livestock and Wildlife, K. L. Launchbaugh, D. Sanders, and J. C. Mosely, Eds., pp. 60-69, University of Idaho, Moscow, Idaho, USA, 1999.

[13] K. K. Wagner and D. L. Nolte, "Comparison of active ingredients and delivery systems in deer repellents," Wildlife Society Bulletin, vol. 29, no. 1, pp. 322-330, 2001.

[14] B. A. Kimball, J. Taylor, K. R. Perry, and C. Capelli, "Deer responses to repellent stimuli," Journal of Chemical Ecology, vol. 35, no. 12, pp. 1461-1470, 2009.

[15] J. Beguin, D. Pothier, and M. Prévost, "Can the impact of deer browsing on tree regeneration be mitigated by shelterwood cutting and strip clearcutting?" Forest Ecology and Management, vol. 257, no. 1, pp. 38-45, 2009.

[16] B. A. Kimball, E. C. Turnblom, D. L. Nolte, D. L. Griffin, and R. M. Engeman, "Effects of thinning and nitrogen fertilization on sugars and terpenes in Douglas-fir vascular tissues: implications for black bear foraging," Forest Science, vol. 44, no. 4, pp. 599-602, 1998.

[17] B. A. Kimball, D. L. Nolte, D. L. Griffin, S. M. Dutton, and S. Ferguson, "Impacts of live canopy pruning on the chemical constituents of Douglas-fir vascular tissues: implications for black bear tree selection," Forest Ecology and Management, vol. 109, no. 1-3, pp. 51-56, 1998.

[18] P. Feeny, "Plant apparency and chemical defense," in Biological Interactions Between Plants and Insects, J. W. Wallace and R. L. Nansel, Eds., vol. 1, pp. 1-40, Plenum Press, New York, NY, USA, 1976.

[19] D. F. Rhoades and G. A. Rosenthal, "Evolution of plant chemical defense against herbivores," in Herbivores: Their Interactions with Secondary Plant Metabolites, D. H. Janzen, Ed., vol. 1, pp. 3-54, Academic Press, New York, NY, USA, 1979.

[20] P. D. Coley, J. P. Bryant, and F. S. Chapin, "Resource availability and plant antiherbivore defense," Science, vol. 230, no. 4728, pp. 895-899, 1985.

[21] J. M. O’Reilly-Wapstra, B. M. Potts, C. McArthur, and N. W. Davies, "Effects of nutrient variability on the genetic-based resistance of Eucalyptus globulus to a mammalian herbivore and on plant defensive chemistry," Oecologia, vol. 142, no. 4, pp. 597-605, 2005.

[22] S. E. Hartley, K. Nelson, and M. Gorman, "The effect of fertiliser and shading on plant-chemical composition and palatability to Orkney voles, Microtus arvalis orcadensis," Oikos, vol. 72, no. 1, pp. 79-87, 1995.

[23] J. Koricheva, S. Larsson, E. Haukioja, and M. Keinanen, "Regulation of woody plant secondary metabolism by resource availability: hypothesis testing by means of meta-analysis," Oikos, vol. 83, no. 2, pp. 212-226, 1998.

[24] J. S. Powell and K. F. Raffa, "Sources of variation in concentration and composition of foliar monoterpenes in tamarack (Larix laricina) seedlings: roles of nutrient availability, time of season, and plant architecture," Journal of Chemical Ecology, vol. 25, no. 8, pp. 1771-1797, 1999.

[25] E. Ormeño, V. Baldy, C. Ballini, and C. Fernandez, "Production and diversity of volatile terpenes from plants on calcareous and siliceous soils: effect of soil nutrients," Journal of Chemical Ecology, vol. 34, no. 9, pp. 1219-1229, 2008.

[26] G. Vourc'h, B. Vila, D. Gillon et al., "Disentangling the causes of damage variation by deer browsing on young Thuja plicata," Oikos, vol. 98, no. 2, pp. 271-283, 2002. 
[27] G. Vourc'h, M. Garine-Wichatitsky, A. Labbé, D. Rosolowski, J. L. Martin, and H. Fritz, "Monoterpene effect on feeding choice by deer," Journal of Chemical Ecology, vol. 28, no. 12, pp. 2411-2427, 2002.

[28] B. A. Kimball, J. H. Russell, D. L. Griffin, and J. J. Johnston, "Response factor considerations for the quantitative analysis of western redcedar (Thuja plicata) foliar monoterpenes," Journal of Chromatographic Science, vol. 43, no. 5, pp. 253-258, 2005.

[29] SAS/STAT, SAS. 9.2, SAS Institute, Cary, NC, USA, 2008.

[30] Y. Benjamini and Y. Hochberg, "Controlling the false discovery rate-a practical and powerful approach to multiple testing," Journal of the Royal Statistical Society: B, vol. 57, no. 1, pp. 289300, 1995.

[31] B. A. Kimball, W. M. Arjo, and J. J. Johnston, "Single point calibration with a non-linear detector: carbohydrate analysis of conifer needles by hydrophic interaction chromatographyevaporative light-scattering detection (HIC-ELSD)," Journal of Liquid Chromatography and Related Technologies, vol. 27, no. 12, pp. 1835-1848, 2004.

[32] F. D. Provenza, "Acquired aversions as the basis for varied diets of ruminants foraging on rangelands," Journal of Animal Science, vol. 74, no. 8, pp. 2010-2020, 1996.

[33] J. J. Villalba and F. D. Provenza, "Foraging in chemically diverse environments: energy, protein, and alternative foods influence ingestion of plant secondary metabolites by lambs," Journal of Chemical Ecology, vol. 31, no. 1, pp. 123-138, 2005.

[34] B. A. Kimball and D. L. Nolte, "Herbivore experience with plant defense compounds influences acquisition of new flavor aversions," Applied Animal Behaviour Science, vol. 91, no. 1-2, pp. 17-34, 2005.

[35] B. A. Kimball, F. D. Provenza, and E. A. Burritt, "Importance of alternative foods on the persistence of flavor aversions: implications for applied flavor avoidance learning," Applied Animal Behaviour Science, vol. 76, no. 3, pp. 249-258, 2002.

[36] B. A. Kimball and V. Billings, "Do herbivores associate flavours with specific consequences in flavour aversion learning?" Applied Animal Behaviour Science, vol. 107, no. 3-4, pp. 252261, 2007.

[37] S. Elliott and A. Loudon, "Effects of monoterpene odors on food selection by red deer calves (Cervus -Elaphus)," Journal of Chemical Ecology, vol. 13, no. 6, pp. 1343-1349, 1987.

[38] J. W. Hanover, "Genetics of terpenes. I. Gene control of monoterpene levels in Pinus monticola dougl," Heredity, vol. 21, pp. 73-84, 1966.

[39] S. V. Kossuth, E. Mccall, J. Ledbetter et al., "Clone certification by use of cortical monoterpenes as biochemical markers," Silvae Genetica, vol. 37, pp. 73-76, 1988.

[40] K. M. Stewart, T. E. Fulbright, and D. L. Drawe, "White-tailed deer use of clearings relative to forage availability," Journal of Wildlife Management, vol. 64, no. 3, pp. 733-741, 2000.

[41] D. P. W. Huber, S. Ralph, and J. Bohlmann, "Genomic hardwiring and phenotypic plasticity of terpenoid-based defenses in conifers," Journal of Chemical Ecology, vol. 30, no. 12, pp. 2399-2418, 2004.

[42] K. J. Moore and H. J. G. Jung, "Lignin and fiber digestion," Journal of Range Management, vol. 54, no. 4, pp. 420-430, 2001.

[43] J. P. Bryant, F. D. Provenza, J. Pastor, P. B. Reichardt, T. P. Clausen, and J. T. Dutoit, "Interactions between woody-plants and browsing mammals mediated by secondary metabolites," Annual Review of Ecology and Systematics, vol. 22, pp. 431-446, 1991.
[44] F. D. Provenza, J. A. Pfister, and C. D. Cheney, "Mechanisms of learning in diet selection with reference to phytotoxicosis in herbivores," Journal of Range Management, vol. 45, no. 1, pp. 36-45, 1992.

[45] J. Kamler, M. Homolka, M. Barančeková, and J. KrojerováProkešová, "Reduction of herbivore density as a tool for reduction of herbivore browsing on palatable tree species," European Journal of Forest Research, vol. 129, no. 2, pp. 155$162,2010$. 

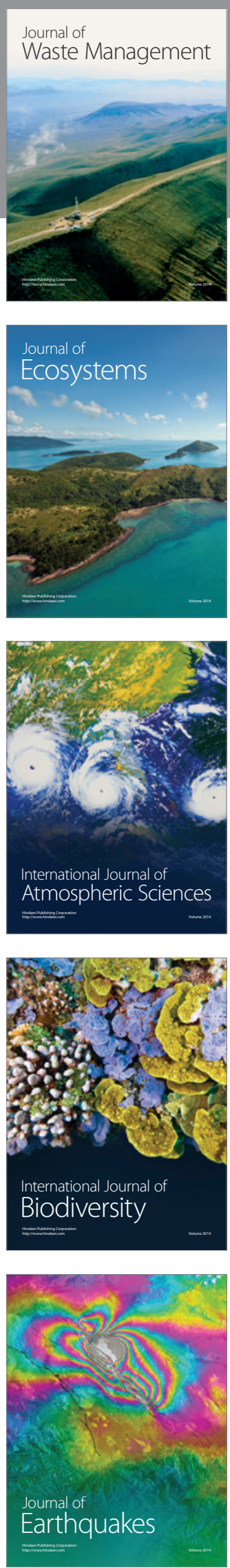
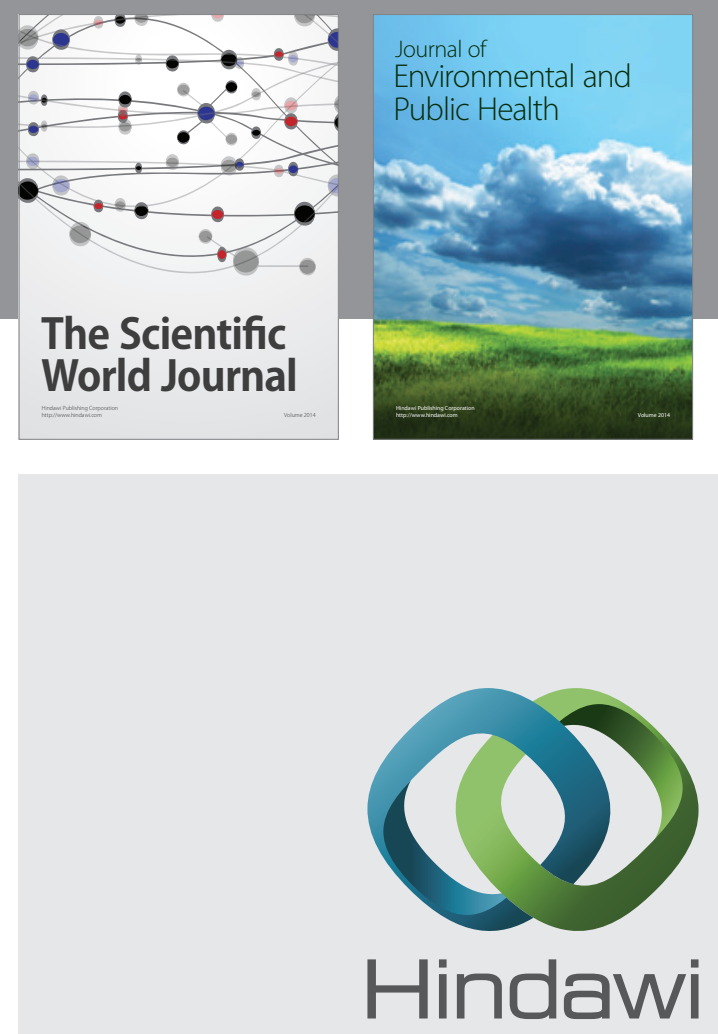

Submit your manuscripts at

http://www.hindawi.com
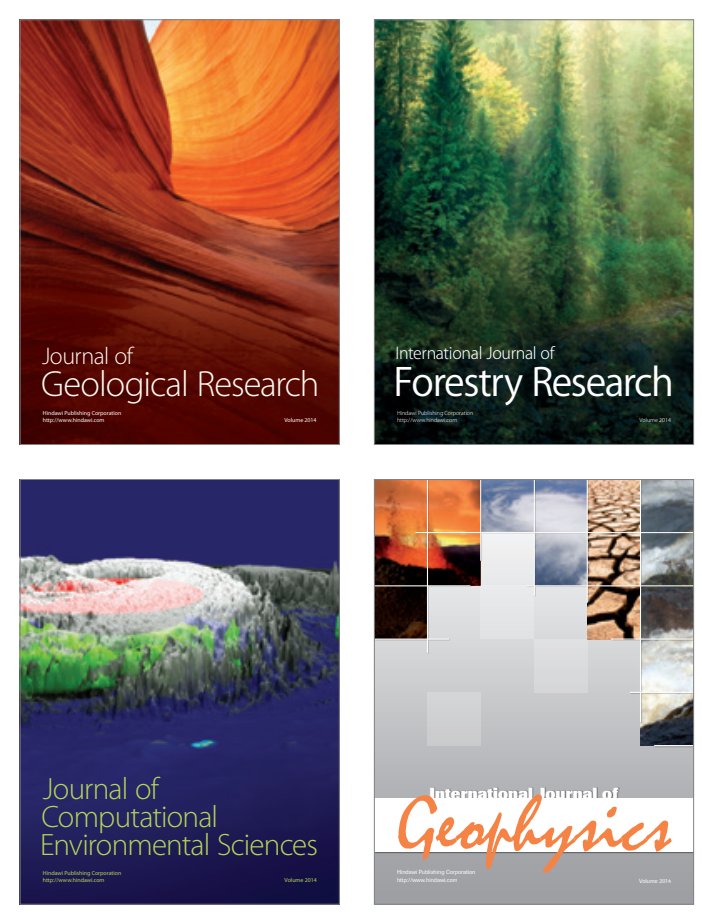
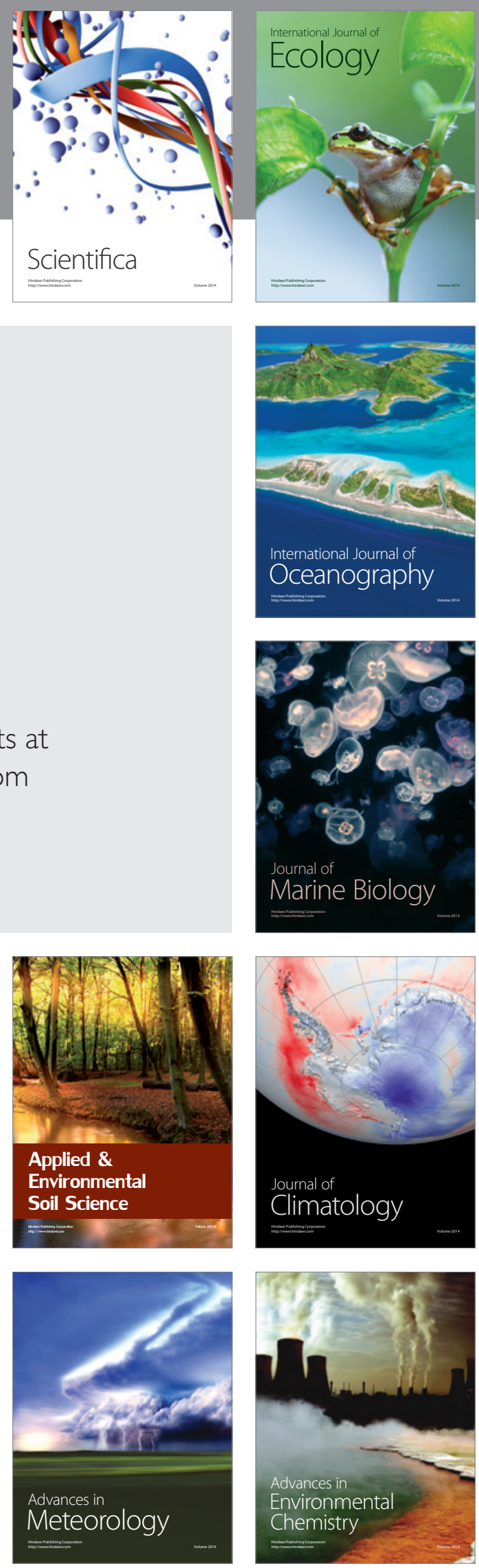